ISSN = 1980-993X - doi:10.4136/1980-993X
www.ambi-agua.net
E-mail: ambi-agua@agro.unitau.br
Tel.: (12) 3625-4212

\title{
Effect of the bentonite application on the cadmium mobility in an Argisol
}

\author{
(http://dx.doi.org/10.4136/ambi-agua.901) \\ Gilvanise Alves Tito ${ }^{1}$ Lúcia Helena Garófalo Chaves²; \\ Hugo Orlando Carvallo Guerra ${ }^{3}$ \\ Departamento de Engenharia Agrícola, Universidade Federal de Campina Grande - PB \\ e-mails: ${ }^{2}$ gilvanisetito@yahoo.com.br, ${ }^{2}$ lhgarofalo@ hotmail.com, \\ ${ }^{3}$ hugo_carvallo@hotmail.com
}

\begin{abstract}
Aiming to evaluate the effect of doses of bentonite $\left(0,30\right.$ and $\left.60 \mathrm{t} \mathrm{ha}^{-1}\right)$ in the mobility of cadmium on an Argisol, tests of mobility in soil columns with different cadmium concentrations $\left(50,250\right.$ and $450 \mathrm{mg} \mathrm{kg}^{-1}$ of soil) and steady state flux, were conducted, determining its flux density and percolation velocity. The cadmium was dislocated by pulse, the solution containing the cadmium initially infiltrated into the soil for a given time period and afterwards the soil was lixiviated with distilled water. Leachates were collected every 10 minutes during 80 minutes of water percolation. The solutions percolated, expressed in pore volumes, were $6.33,2.28$ and 1.93 for the 0,30 and $60 \mathrm{t} \mathrm{ha}^{-1}$ of bentonite, respectively, being one pore volume equal to $1.22 \mathrm{~cm}^{3}$. The concentration of cadmium was measured by atomic absorption spectrophotometry. At the end of the experiment, the columns were dismounted and the concentrations of cadmium in the soil at different depths (0-10, 10-20, 20-30 e 30-40 $\mathrm{cm})$ were also determined. The results showed that the flux density and velocity of water percolation of the water solution were significantly reduced by the addition of bentonite to the soil. The levels of cadmium in the soil did not affect these mobility parameters. Increasing doses of bentonite favored the adsorption of cadmium in the soil.
\end{abstract}

Keywords: heavy metal, miscible displacement, clay mineral.

\section{Efeito da aplicação de bentonita na mobilidade de cádmio em Argissolo}

\section{RESUMO}

Objetivando-se avaliar o efeito da aplicação de doses de bentonita $\left(0,30\right.$ e $\left.60 \mathrm{t} \mathrm{ha}^{-1}\right)$ na mobilidade do cádmio num Argissolo, realizaram-se ensaios de mobilidade do referido metal em colunas de solo com diferentes concentrações de cádmio (50, 250 e $450 \mathrm{mg} \mathrm{de} \mathrm{kg}{ }^{-1} \mathrm{de}$ solo) submetidas a lixiviação num regime saturado, determinando-se a densidade do fluxo e a velocidade de fluxo. O cádmio foi deslocado por pulso, isto é, a solução contendo o cádmio inicialmente infiltrou no solo por um determinado tempo quando então a lixiviação foi continuada com água destilada. Lixiviados foram coletados a cada 10 minutos durante 80 minutos de percolação. As soluções percoladas, expressas em volume de poros, foram 6,33; 2,28 e 1,93 para os tratamentos de bentonita de 0,30 e $60 \mathrm{t} \mathrm{ha}^{-1}$ sendo um volume de poros igual a $1,22 \mathrm{~cm}^{3}$. As concentrações de cádmio determinadas por espectrofotometria de absorção atômica. Ao final dos ensaios, as colunas foram desmontadas e as concentrações de cádmio no solo a diferentes profundidades $(0-10,10-20,20-30$ e 30-40 cm), foram também 
TITO, G. A.; CHAVES, L. H. G.; GUERRA, H. O. C. Effect of the bentonite application on the cadmium mobility in an Argissol. Ambi-Agua, Taubaté, v. 7, n. 2, p. 18-29, 2012. (http://dx.doi.org/10.4136/ambiagua.901)

determinadas. Os resultados permitiram concluir que a densidade de fluxo e a velocidade de fluxo da solução foram reduzidas significativamente com a incorporação de bentonita ao solo. Os teores de cádmio do solo não afetaram a densidade de fluxo nem a velocidade de fluxo da solução. $\mathrm{O}$ aumento das doses de bentonita favoreceu a adsorção do cádmio pelo solo.

Palavras-chaves: metal pesado, deslocamento miscível, mineral de argila.

\section{INTRODUCTION}

In recent years, environmental pollution has reached alarming levels causing a great concern to the society, creating a conscience of environmental preservation. One of the problems that most affect the water environment is the organic or inorganic pollution resulting from residential and industrial effluents, in which the presence of heavy metals may occur. Cadmium $(\mathrm{Cd})$ is a highly toxic metal and has been described as the most dangerous of all the contaminants metals in the environment (Albertini et al., 2001; Guimarães et al., 2008). When added to soil it is absorbed rapidly increasing dramatically the accumulated level of the element (Paganini et al., 2004). According to Malavolta (1994) Cd available concentrations in the soil above $3 \mathrm{mg} \mathrm{kg}^{-1}$ are considered toxic, inadequate for the cultivation of human consumption plants.

The contaminant accumulation and transport processes in the soil depend of the soil type and the contaminant nature. The $\mathrm{pH}$, the organic matter, the cation exchange capacity, the specific surface and the ionic forces are soil attributes that correlate well with the adsorption of cadmium. The composition and the properties of the cadmium contaminant are significant factors on the development of the interactions with the soil subtract. The interactions between the soil and the cadmium determinate the fate and mobility of cadmium in the environment and they are the result of adsorption, complexation, dissolution, and precipitation reactions in the soil. However, although these processes occur simultaneously, the adsorption reactions are probably the one that more affect the availability of cadmium in the soil (Camargo, 2006).

The use of low quality irrigation water, the application of sewage sludge as source of nutrients for plants and the indiscriminate use of agrotoxics are dangerous sources of pollution, especially of heavy metals. According to Costa et al. (2007), the impact of heavy metal contamination should not be evaluated only by its soil total content, but by their bioavailability, which is a property related to its mobility in soil and uptake by plants.

One of the procedures proposed to reduce the mobility and bioavailability of metals, is the use of adsorbent materials, such as clay minerals (Rodrigues et al., 2004; Chui, 2005; Lacin et al., 2005). The sorption of cations can cause a real transfer of pollutants from the liquid to the solid phase. The mobility of solutes in soil is inversely related to the adsorption of the soil and the environmental conditions that favor chemical precipitation (Matos et al., 2001; Chaves et al., 2008).

The bentonite is a clay mineral constituted mainly of smectite, usually known as montmorillonite. Expansive and predominantly negative charged shows a high cation exchange capacity (CEC). In general, clay minerals are considered to be the active part of the soil, influencing the retention and movement of soil water, adsorption and ion exchange (Meurer, 2004), the latter being the most important mechanism for adsorption of inorganic pollutants such as heavy metals. Due to its sorbent properties, its low cost and feasibility to obtain it (the State of Paraiba is currently the largest bentonite producer in Brazil) studies have been conducted to evaluate the properties of the bentonite as a sorbent for heavy metals (Santos et al., 2002; Rodrigues et al., 2004; Lacin et al., 2005). Thus, the present study aimed to evaluate the effect of bentonite on the mobility of cadmium in soil columns, determining 
TITO, G. A.; CHAVES, L. H. G.; GUERRA, H. O. C. Effect of the bentonite application on the cadmium mobility in an Argissol. Ambi-Agua, Taubaté, v. 7, n. 2, p. 18-29, 2012. (http://dx.doi.org/10.4136/ambiagua.901)

the flux density and velocity of the solution, and the amount of $\mathrm{Cd}$ leached and remaining in the soil columns after application of different pore volumes of water.

\section{MATERIALS AND METHODS}

The experiment was conducted at the Agricultural Engineering Department in Campina Grande, Paraiba State, Brazil using a dystrophic Argisol. The bentonite clay used was collected at a deposit (Primavera) located in the city of Boa Vista, Paraiba, Brazil. The clay was analyzed by X-ray diffraction using the XRD 6000 equipment with a radiation of $\mathrm{K} \alpha \mathrm{Cu}$ $(40 \mathrm{kV} / 30 \mathrm{~mA})$. Figure 1 shows the $\mathrm{X}$-ray diffractogram of the bentonite showing characteristic peaks of the smectite clay mineral, the main component of the bentonite, as well as the presence, in minor amount, of silicon oxide peaks. The X-ray analysis was conducted at the Ceramics Laboratory of the Materials Engineering Department, Federal University of Campina Grande-PB.

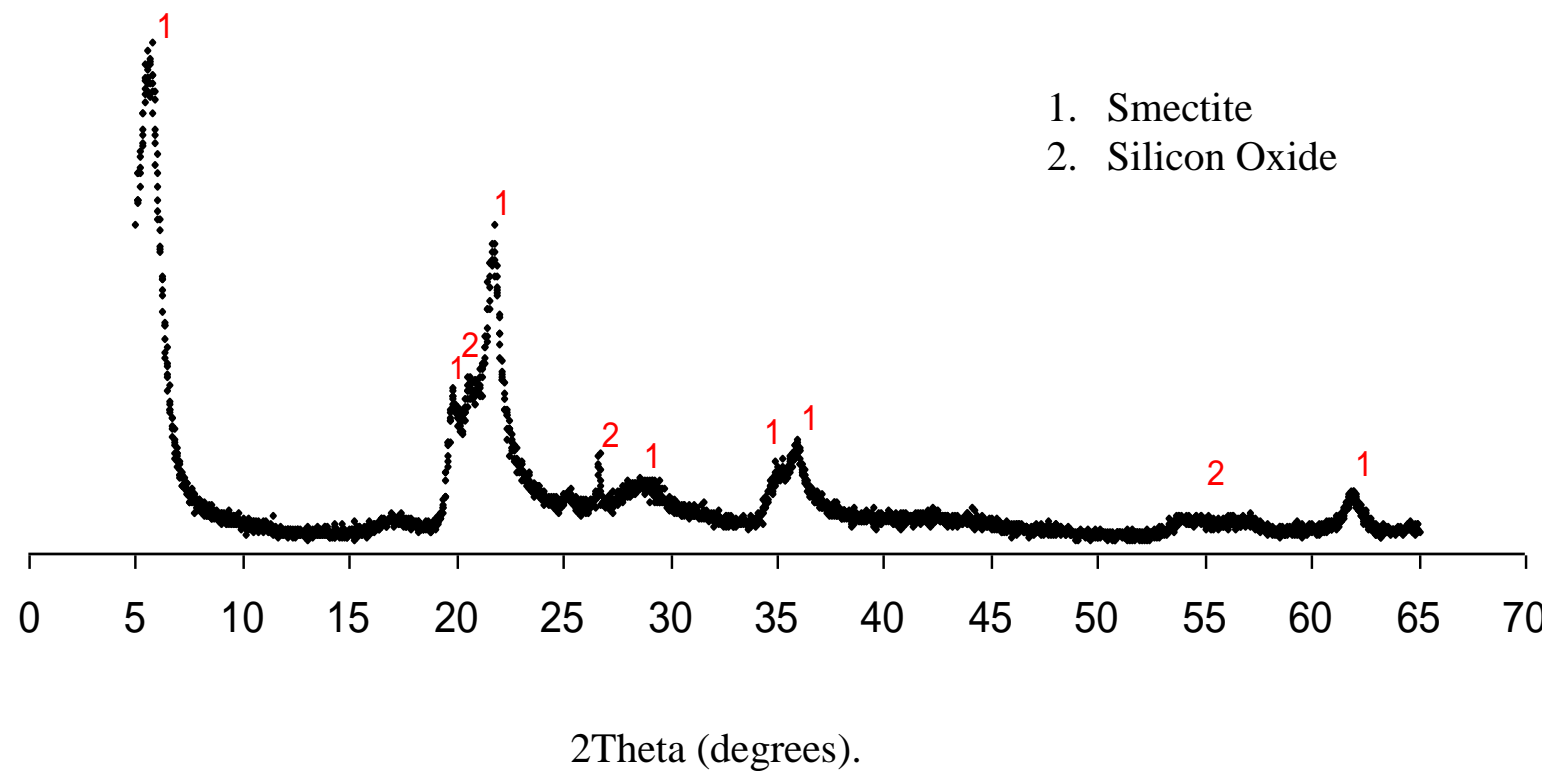

Figure 1. Diffractogram of bentonite obtained by X-ray diffraction.

X-ray fluorescent analysis of the clay were also conducted at the Ceramics Laboratory of the Materials Engineering Department, Federal University of Campina Grande-PB, with the EDX 720, being quantified: $\mathrm{SiO}_{2}=76.09 \% ; \mathrm{Al}_{2} \mathrm{O}_{2}=14.51 \% ; \mathrm{Fe}_{2} \mathrm{O}_{3}=5.21 \% ; \mathrm{MgO}=2.22 \%$; $\mathrm{CaO}=0.76 \% ; \mathrm{TiO}_{2}=0.55 \% ; \mathrm{BaO}=0.19 \% ; \mathrm{K}_{2} \mathrm{O}=0.18 \% ; \mathrm{MnO}=0.028 \% ;$ $\mathrm{Cr}_{2} \mathrm{O}_{3}=0.023 \% ; \mathrm{SrO}=0.008 \% ; \mathrm{ZnO}=0.004 \%$ and calcined residues $=0.23 \%$.

The soil sample was air dried, passed through a $2 \mathrm{~mm}$ mesh opening sieve and analyzed with respect to their physical and chemical characteristics (Table 1)

Four kilograms of soil were mixed with $0.00 ; 0.45$ and $0.90 \mathrm{~kg}$ of bentonite, corresponding to the doses of 0 (B0), 30 (B30) and 60 (B60) $\mathrm{t} \mathrm{ha}^{-1}$. These mixtures were left to rest during 30 days, allowing the reaction between soil and bentonite. After this period, the mixtures were again air dried and passed through a $2 \mathrm{~mm}$ sieve. A cadmium solution, prepared from $\mathrm{CdCl}_{2} . \mathrm{H}_{2} \mathrm{O}$, was added to the soil to obtain equivalent concentrations of 50 , 250 and $450 \mathrm{mg} \mathrm{kg}^{-1}$ of soil. 
TITO, G. A.; CHAVES, L. H. G.; GUERRA, H. O. C. Effect of the bentonite application on the cadmium mobility in an Argissol. Ambi-Agua, Taubaté, v. 7, n. 2, p. 18-29, 2012. (http://dx.doi.org/10.4136/ambiagua.901)

Table 1. Physical and Chemical characteristics of the Argisol used in the experiment.

\begin{tabular}{|c|c|}
\hline Characterístics & Value \\
\hline Sand $\left(\mathrm{g} \mathrm{kg}^{-1}\right)$ & 867.9 \\
\hline Silt $\left(\mathrm{g} \mathrm{kg}^{-1}\right)$ & 40.3 \\
\hline Clay $\left(\mathrm{g} \mathrm{kg}^{-1}\right)$ & 91.8 \\
\hline Textural class & sand \\
\hline Field Capacity (\%) & 24.42 \\
\hline Permanent Wilting Point (\%) & 3.88 \\
\hline Density & 1.56 \\
\hline Particle Density & 2.55 \\
\hline Total Porosity (\%) & 39.0 \\
\hline $\mathrm{pH}$ & 5.79 \\
\hline Electrical Conductivity $\left(\mathrm{dS} \mathrm{m}^{-1}\right)$ & 0.37 \\
\hline Phosphorus* (mg dm ${ }^{-3}$ ) & 18.3 \\
\hline Potassium** $\left(\mathrm{cmol}_{\mathrm{c}} \mathrm{kg}^{-1}\right)$ & 0.05 \\
\hline Sodium** $\left(\mathrm{cmol}_{\mathrm{c}} \mathrm{kg}^{-1}\right)$ & 0.03 \\
\hline Calcium** $\left(\mathrm{cmol}_{\mathrm{c}} \mathrm{kg}^{-1}\right)$ & 2.61 \\
\hline Magnesium $* *\left(\mathrm{cmol}_{\mathrm{c}} \mathrm{kg}^{-1}\right)$ & 0.83 \\
\hline $\mathrm{H}^{+}+\mathrm{Al}^{2+}\left(\mathrm{cmol}_{\mathrm{c}} \mathrm{kg}^{-1}\right)$ & 1.48 \\
\hline Cation Exchange Capacity ${ }_{\text {pot }}\left(\mathrm{cmol}_{\mathrm{c}} \mathrm{kg}^{-1}\right)$ & 5.00 \\
\hline Organic Carbon \% & 0.94 \\
\hline Organic Matter g/kg & 16.2 \\
\hline Zinc* $\left(\mathrm{mg} \mathrm{kg}^{-1}\right)$ & 0.264 \\
\hline Copper* $\left(\mathrm{mg} \mathrm{kg}^{-1}\right)$ & 0.074 \\
\hline Cadmium* $\left(\mathrm{mg} \mathrm{kg}^{-1}\right)$ & 0.017 \\
\hline
\end{tabular}

The experimental design was a completely randomized in a $3 \times 3$ factorial arrangement (three doses of bentonite and three cadmium concentrations), with three replicates, totalizing 27 experimental units. Each experimental unit consisting of a PVC column, $500 \mathrm{~mm}$ height and $100 \mathrm{~mm}$ in diameter filled with $4 \mathrm{~kg}$ of soil plus bentonite. The columns were constructed of five rings $100 \mathrm{~mm}$ in height superimposed and joined with silicone glue. These rings facilitate the removal of samples of solid material at different depths at the end of experiment. At the bottom of the column was placed a cap with a PVC tube adapted in its center to drain 
TITO, G. A.; CHAVES, L. H. G.; GUERRA, H. O. C. Effect of the bentonite application on the cadmium mobility in an Argissol. Ambi-Agua, Taubaté, v. 7, n. 2, p. 18-29, 2012. (http://dx.doi.org/10.4136/ambiagua.901)

the percolated solution (Figure 2). Over the cap was placed an screen filter paper to support the solid material. The columns were filled with the soil bentonite mixture compacting with a socket each layer applied in order to provide uniformity in the density throughout the soil column. The columns were connected to a Mariotte bottle containing distilled water and saturated by capillary rise, then the columns were submitted to a constant flux maintaining a constant water level of $80 \mathrm{~mm}$ above the soil surface.

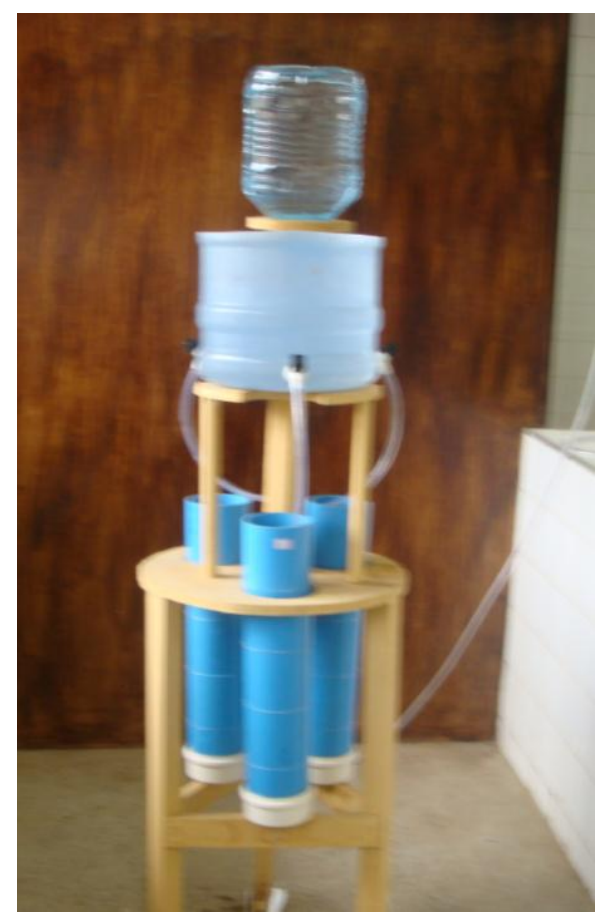

Figure 2. Set up utilized for mobility tests with three plastic columns filled with soil and bentonite.

After stabilization of the flow, the water supply at the top of each column was stopped and allowed to drain one pore volume of solution. At the end of the drainage, the bottom of the columns were closed and on top of them added a pore volume of metal solution equivalent to 50,250 and $450 \mathrm{mg} \mathrm{kg}^{-1}$ cadmium concentrations allowing to stand during 24 hours to facilitate the reactions among the soil mixture and the cadmium. After this period, the drains were opened again, and the supply of mineral water restarted and the percolation reinitiated, keeping the hydraulic charge of $80 \mathrm{~mm}$ of water. The percolation lasted 80 minutes removing leachates every 10 minutes. The solutions percolated, expressed in pore volumes, were 6.33, 2.28 and 1.93 for the 0,30 and $60 \mathrm{t} \mathrm{ha}^{-1}$ of bentonite.

The soil column pore volume was determined using the following equation:

$$
\mathrm{PV}=\pi \mathrm{r}^{2} \mathrm{~h}\left(1-\mathrm{ds} \mathrm{dp^{-1 } )}\right.
$$

where:

$\mathrm{PV}$ is the pore volume $\left(\mathrm{cm}^{3}\right), \mathrm{r}$ the column ratio $(\mathrm{cm}), \mathrm{h}$ the column length $(\mathrm{cm})$, and $\mathrm{ds} \mathrm{e}$ $\mathrm{dp}$ the soil density and particle density, respectively. The pore volume of the soil column was $1.22 \mathrm{~cm}^{-3}$.

To determine the cadmium content in the percolates, the solution samples collected were placed in polypropylene bottles, identified and stored in refrigerator until preparation for 
TITO, G. A.; CHAVES, L. H. G.; GUERRA, H. O. C. Effect of the bentonite application on the cadmium mobility in an Argissol. Ambi-Agua, Taubaté, v. 7, n. 2, p. 18-29, 2012. (http://dx.doi.org/10.4136/ambiagua.901)

quantification of the metal by atomic absorption spectrophotometry. At the end of the tests, the columns were dismounted separating the rings that composed it. The solid material contained in each ring was left to air dry, weighed and sieved to $2 \mathrm{~mm}$ mesh. The concentration of cadmium in the soil was determined using the normally used Mehlich extraction solution (Embrapa, 1997). The standard EPA procedures, very used in the laboratories, were not adopted; although the procedures of digestion and removal of metal are more efficient according with Silva et al. (2007) the EPA method has limitations to determine nickel and cadmium in the soil, because does not solubilizes the precipitated or occluded metals. For this, it would be necessary to conduct the extraction with fluorhidric acid, which is highly corrosive, of dangerous handling and responsible for damage to the instruments that conduct the analysis.

The mobility parameters of the cadmium in the soil (flux density and velocity) were determined using the DISP software developed at the Agricultural Engineering Department of the Federal University of Viçosa, by Borges Júnior and Ferreira (2006). The computational soft DISP calculates the parameters of soil solute transport equations, based on adjustment of theoretical models to observed data, as well as performs simulations for the space and temporary variations of the concentration and balance of the solute mass in the soil profile. The DISP uses the least-squares method to obtain the diffusion-dispersion coefficient and retardation factor parameters. Comparative tests between DISP and the program CXTFIT, relative to the calculations of the Peclet number and retardation factor parameters, pointed out equivalence between both programs, however the graphic interface in DISP makes its use more feasible in relation to CXTFIT. The CXTFIT 2.0 program provides a convenient way of solving direct and inverse problems for one-dimensional solute transport during steady water flow. PHREEQC and HYDRUS 1D, 2D, 3D models were not necessary to use. The input parameters for the DISP were the observed absolute cadmium concentrations $(\mathrm{C})$ for different pore volumes, soil water content (equal to saturation because the flux was under saturated conditions), soil density, column length, initial and final cadmium concentration.

The results obtained were subjected to analysis of variance, using the SISVAR program (Ferreira, 2003).

\section{RESULTS AND DISCUSSION}

The flux density and velocity of the solution were significantly influenced at the $1 \%$ probability level by the bentonite treatment. The increasing concentration of $\mathrm{Cd}$ and the interaction between $\mathrm{Cd}$ concentrations and doses of bentonite, were not significant (Table 2).

Applications of 30 and $60 \mathrm{t} \mathrm{ha}^{-1}$ bentonite compared to control $\left(0 \mathrm{t} \mathrm{ha}^{-1}\right)$ reduced the flux density in 72.62 and $78.63 \%$ and the percolation rate in 76.27 and $83.00 \%$, respectively. The beneficial effect of bentonite application can be attributed to the fact that this clay has a large quantity of micropores which difficult the passage of water and solutes through the soil, and also because its high specific surface favors cation exchange. Water moves more quickly through the large pores and spaces in a sandy soil, as the one used on this study, than it does through the small pores in a clayey soil; thus addition of bentonite clay to the soil favors the retention of water and pollutants. A low flow velocity and a high adsorption of the pollutant by the clay reduce risks of contamination by percolation.

According Jesus (2004), the migration and retention of pollutants in the soil is influenced, among other factors, by the mineralogy and cation exchange capacity of the soil. Because the reactions among the clay and pollutants are not instantaneous, if the flow velocity is relatively high, the cations do not have chance to be retained by the soil, being percolated and contaminating the subsoil waters (Freeze and Cherry, 1979). 
TITO, G. A.; CHAVES, L. H. G.; GUERRA, H. O. C. Effect of the bentonite application on the cadmium mobility in an Argissol. Ambi-Agua, Taubaté, v. 7, n. 2, p. 18-29, 2012. (http://dx.doi.org/10.4136/ambiagua.901)

Table 2. Summary of variance analysis and mean comparison test for the flow density and velocity as affected by cadmium and bentonite treatments.

\begin{tabular}{|c|c|c|c|}
\hline \multirow{2}{*}{$\begin{array}{l}\text { Sources of } \\
\text { variation }\end{array}$} & \multirow{2}{*}{$\begin{array}{l}\text { Degrees of } \\
\text { Freedom }\end{array}$} & \multicolumn{2}{|c|}{ Mean Square } \\
\hline & & Flux Density & Flow Velocity \\
\hline Cadmium (C) & 2 & $74.91 \mathrm{~ns}$ & $492.47 \mathrm{~ns}$ \\
\hline Bentonite (B) & 2 & $11742.6^{* *}$ & $77203.2^{* *}$ \\
\hline $\mathrm{C} \times \mathrm{B}$ & 4 & $132.46 \mathrm{~ns}$ & $870.83 \mathrm{~ns}$ \\
\hline Residue & 18 & 33.76 & 221.94 \\
\hline $\mathrm{CV}(\%)$ & & 14.00 & 14.09 \\
\hline \multicolumn{2}{|l|}{ Bentonite } & \multicolumn{2}{|c|}{ Mean $\left(\mathrm{cm} \mathrm{h}^{-1}\right)$} \\
\hline \multicolumn{2}{|l|}{$0 \mathrm{t} \mathrm{ha}^{-1}$} & 81.67 & 209.4 \\
\hline \multicolumn{2}{|l|}{$30 \mathrm{tha}^{-1}$} & 22.36 & 49.69 \\
\hline \multicolumn{2}{|l|}{$60 \mathrm{t} \mathrm{ha}^{-1}$} & 17.45 & 35.61 \\
\hline \multicolumn{2}{|c|}{ Linear Regression } & $\begin{array}{c}\mathrm{Y}=-30.3 \mathrm{X}+100.9 \\
\mathrm{R}^{2}=80.9 \%\end{array}$ & $\begin{array}{c}\mathrm{Y}=-77.6 \mathrm{X}+258.8 \\
\mathrm{R}^{2}=80.9 \%\end{array}$ \\
\hline \multicolumn{2}{|c|}{ Quadratic Regression } & $\begin{array}{c}\mathrm{Y}=25.5 \mathrm{X}^{2}-132.2 \mathrm{X}+ \\
185.9 \mathrm{R}^{2}=100 \%\end{array}$ & $\begin{array}{c}Y=65.4 X^{2}-339 X+476.8 \\
R^{2}=100 \%\end{array}$ \\
\hline \multicolumn{2}{|l|}{ Cadmium } & \multicolumn{2}{|c|}{ Mean $\left(\mathrm{cm} \mathrm{h}^{-1}\right)$} \\
\hline \multicolumn{2}{|l|}{$50 \mathrm{mg} \mathrm{kg}^{-1}$} & $38.85 \mathrm{a}$ & $99.62 \mathrm{a}$ \\
\hline \multicolumn{2}{|l|}{$250 \mathrm{mg} \mathrm{kg}^{-1}$} & $40.39 \mathrm{a}$ & $89.76 \mathrm{a}$ \\
\hline \multicolumn{2}{|l|}{$450 \mathrm{mg} \mathrm{kg}^{-1}$} & $44.44 \mathrm{a}$ & $90.69 \mathrm{a}$ \\
\hline
\end{tabular}

**, ns, Significant at $1 \%$ (F test) and no significant, respectively. Means followed by the same letter in column do not differ among themselves by Tukey test at $5 \%$ probability

In all the bentonite treatments it was not detected cadmium in the percolated solutions indicating that possibly the cadmium was transformed and retained by the soil in some chemical form, corroborating the results found by Amaral Sobrinho et al. (1999), Anjos and Mattiazzo (2000), Prado and Juliatti (2003), Dal Bosco et al. (2004) and Moreira et al. (2010). One explanation for this is the possible reactions of the cadmium with the oxides present in the soil and bentonite (mainly $\mathrm{Fe}$ and $\mathrm{Al}$ oxides) as shown by the fluorescent analysis described in the Materials and Methods. Wittbroadt and Palmer (1997) working with heavy metals in soil-humic acids also reported that the presence of oxides of $\mathrm{Fe}$ and $\mathrm{Al}$ in the soil has been used to explain the absence of heavy metals in leachates of soils treated with biosolids. Same fact was observed by Nascimento et al. (2010) studying the leaching of lead and zinc in soils treated with steel waste. Another explanation for not detecting $\mathrm{Cd}$ in soil solution in the present study maybe because the $\mathrm{Cd}$ concentrations were below the limit of detection of the instrument used, in this case the atomic absorption spectrometry $\left(0.034 \mathrm{mg} \mathrm{kg}^{-1}\right)$.

Figure 3 shows the distribution curves of cadmium at the 0-10, 10-20, 20-30 and 30-40 $\mathrm{cm}$ soil layers at the end of the experiment and after sectioning the columns. 
TITO, G. A.; CHAVES, L. H. G.; GUERRA, H. O. C. Effect of the bentonite application on the cadmium mobility in an Argissol. Ambi-Agua, Taubaté, v. 7, n. 2, p. 18-29, 2012. (http://dx.doi.org/10.4136/ambiagua.901)
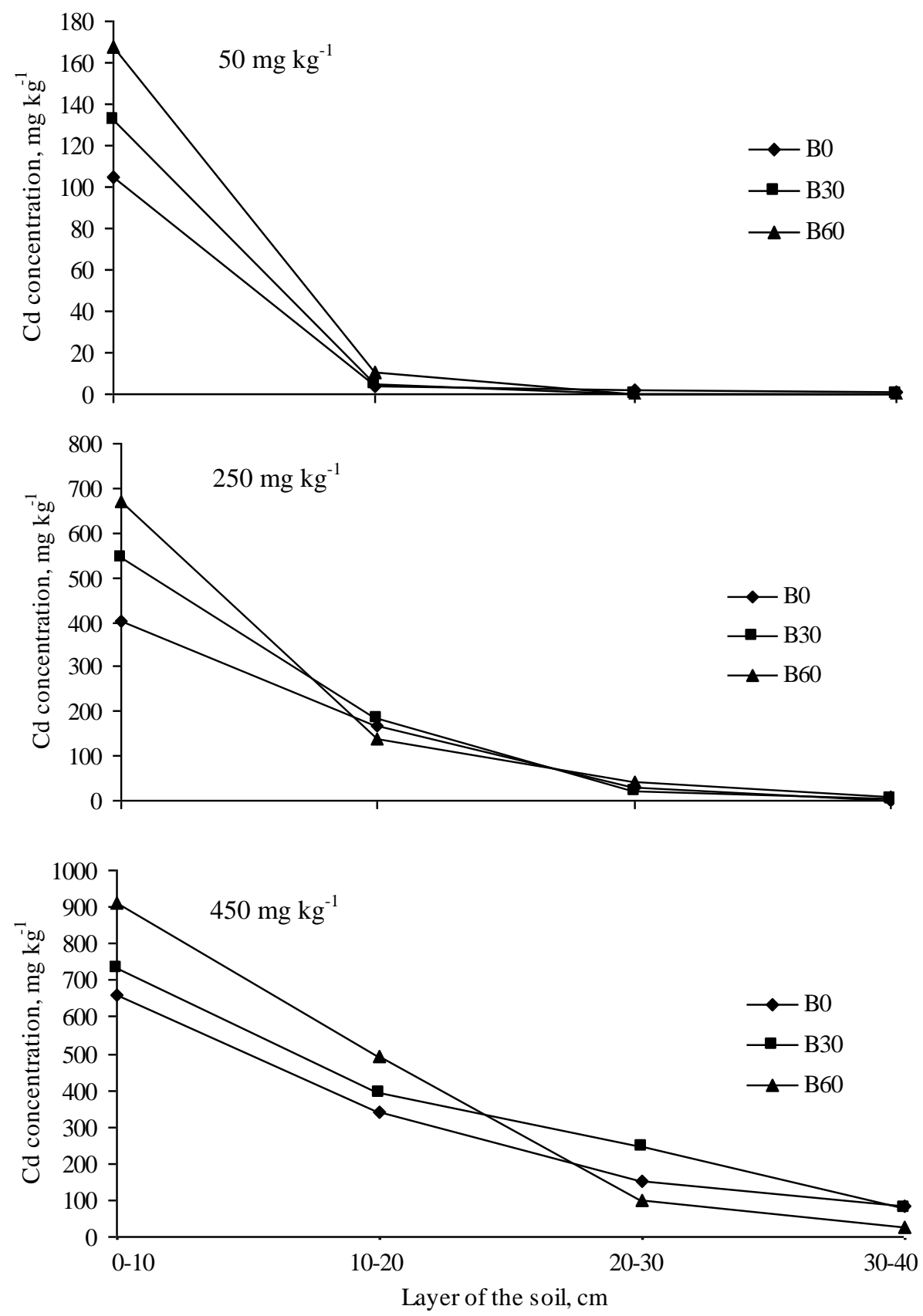

Figure 3. Distribution of the available cadmium in the 0-10, 10-20, 20-30 and $30-40 \mathrm{~cm}$ soil layers of the column after the lixiviation with 7 pore volumes of distilled water, for the different cadmium levels $(50 ; 250$ and $\left.450 \mathrm{mg} \mathrm{kg}^{-1}\right)$ and doses of bentonite applied to the soil $\left(0 ; 30\right.$ and $\left.60 \mathrm{t} \mathrm{ha}^{-1}\right)$.

It was observed that after the lixiviation with 7 pore volumes of distilled water, the highest levels of cadmium in the soil columns, regardless of bentonite concentrations, were found in the first layer of soil column $(0-10 \mathrm{~cm})$ decreasing significantly with depth. Messias et al. (2007) evaluating the mobility of micronutrients in soil treated with sewage sludge, also found that the $\mathrm{Cd}$ was retained most in the first layer of soil. Juliatti et al. (2002) studying the availability and mobility of $\mathrm{Cd}$ in a Red Oxisol observed that the higher concentrations of total $\mathrm{Cd}$ were restricted only to the surface layer of the soil not existing downward movement of the element into the soil. The high concentration of $\mathrm{Cd}$ at the soil surface characterize an strong interaction among the cadmium and the soil, probably a high 
TITO, G. A.; CHAVES, L. H. G.; GUERRA, H. O. C. Effect of the bentonite application on the cadmium mobility in an Argissol. Ambi-Agua, Taubaté, v. 7, n. 2, p. 18-29, 2012. (http://dx.doi.org/10.4136/ambiagua.901)

adsorption already at the surface layer, decreasing with depth to such extent that no Cadmium was detected in the percolated solution. The same was observed by Amaral Sobrinho et al. (1999) studying the lixiviation of Pb, Zn, Cd and Ni in a Yellow Red Podzolic soil.

With respect to the bentonite dose it can confirmed on Figure 3 that the Cd adsorption increased with the addition of bentonite. These results were expected since the bentonite is a 2:1 clay mineral with a high cation exchange and adsorption capacity. Figure 4 shows the total concentration of cadmium found in the soil column after the lixiviation with 7 pore volumes of distilled water for the different bentonite and cadmium treatments studied. Although $\mathrm{Cd}$ was not detected in the percolated solution, the total concentration for $\mathrm{Cd}$ determined in the soil after the dismantling of the columns, was lower than the total quantities of $\mathrm{Cd}$ applied to the soil at the beginning of the experiment. In the soil with $50 \mathrm{mg} \mathrm{kg}^{-1}$ of $\mathrm{Cd}$ were found only $55.68,68.85$ and $89.44 \%$ of the content initially applied to soil columns for the $0 ; 30$ and $60 \mathrm{t} \mathrm{ha}^{-1}$ bentonite treatments, respectively.

The high $\mathrm{Cd}$ concentrations found in the soil column after the lixiviation with 7 pore volumes of distilled water, when compared with the initially applied to the soil can be attributed to the fact that probably the extracting solution utilized by the Mehlich method did not extract the metal in all the forms found in the soil. According to Amaral Sobrinho et al. (2009), the different forms in which heavy metals in the soil may occur (soluble, exchangeable and adsorbed form; occluded in oxides of $\mathrm{Fe}, \mathrm{Al}$ and $\mathrm{Mn}$ form; retained in insoluble organic material form and precipitated forms) are only determined by specific extractors.
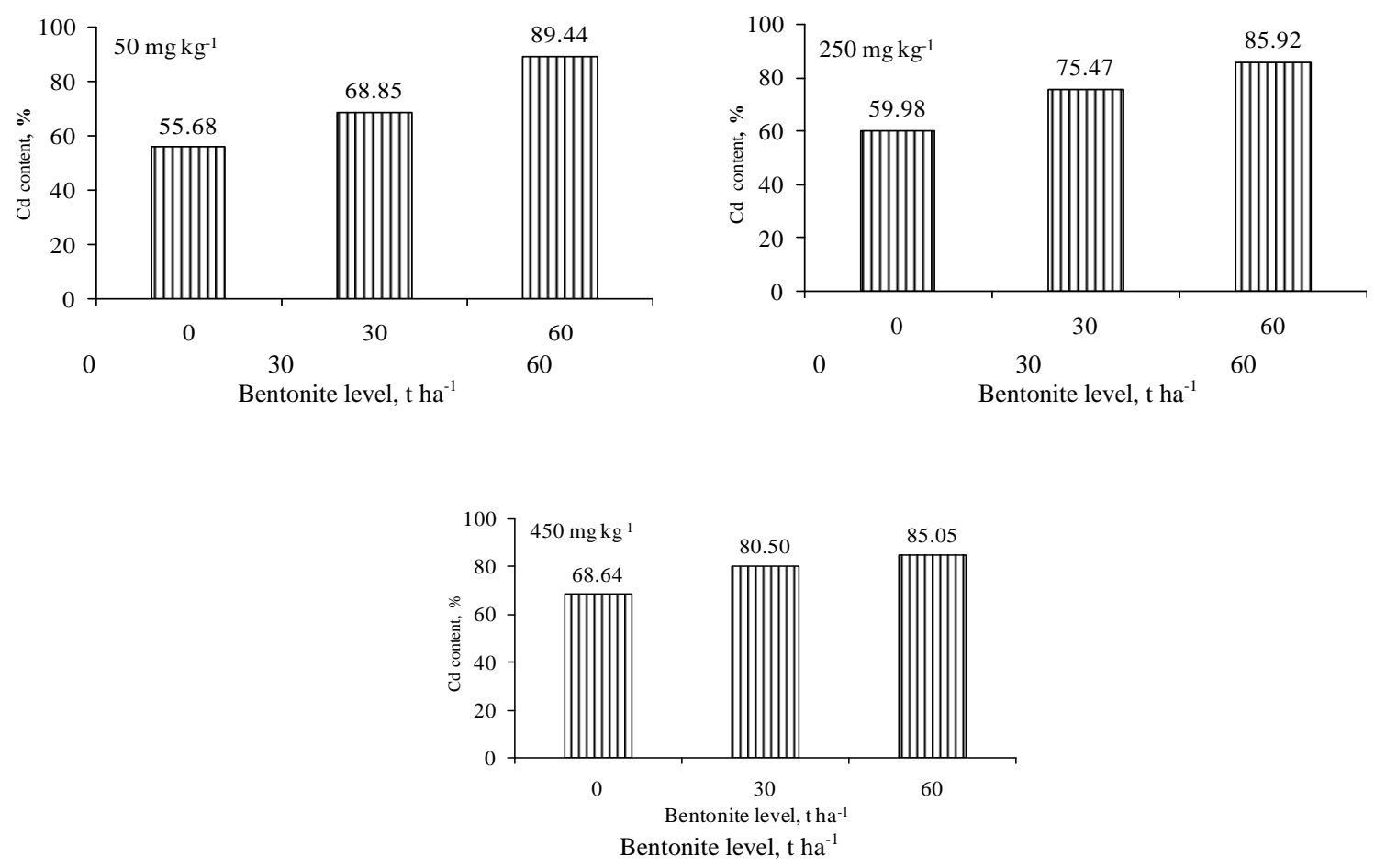

Figure 4. Cadmium content in the soil columns submitted to different cadmium $(50 ; 250$ and $\left.450 \mathrm{mg} \mathrm{kg}^{-1}\right)$ and bentonite $\left(0 ; 30\right.$ and $\left.60 \mathrm{t} \mathrm{ha}^{-1}\right)$ levels.

\section{CONCLUSIONS}

The mobility parameters flux density and percolation velocity of the solution were reduced significantly with the application of bentonite to the sandy soil used; 
TITO, G. A.; CHAVES, L. H. G.; GUERRA, H. O. C. Effect of the bentonite application on the cadmium mobility in an Argissol. Ambi-Agua, Taubaté, v. 7, n. 2, p. 18-29, 2012. (http://dx.doi.org/10.4136/ambiagua.901)

The cadmium content of the soil did not affect the flux density and the percolation rate of the solution;

Increasing doses of bentonite promoted the adsorption of cadmium into the soil.

Practically, there was not mobility of $\mathrm{Cd}$ in the soil column.

\section{ACKNOWLEDGMENTS}

Special thanks to the CNPq for granting the Ph.D. scholarship to the first author and to the Bentonite Union Industry and Commerce Ltda. for the donation of the bentonite.

\section{REFERENCES}

ALBERTINI, S.; CARMO. L. F.; PRADO FILHO, L. G. Isotermas de adsorção de cádmio por Saccharomyces cerevisiae. Ciência e Tecnologia de Alimentos, Campinas, v. 21, n. 2, p. 134-138, 2001. http://dx.doi.org/10.1590/S0101-20612001000200002

AMARAL SOBRINHO, N. M. B.; VELlOSO, A. C. X.; COSTA, L. M. Lixiviação de Pb, Zn, Cd e Ni em solos Podzólico Vermelho Amarelo tratado com resíduos siderúrgicos. Revista Floresta e Ambiente, Seropédica, v. 6, n. 1, p. 65-75, 1999.

AMARAL SOBRINHO, N. M. B.; BARRA, C. M.; LÃ, O. R. Químicas dos metais pesados no solo. In: MELO, V. F.; ALLEONI, L. R. F. (Eds.). Química e mineralogia do solo. Viçosa, MG: SBCS, 2009. v. 2. p. 249-312.

ANJOS, A. R. M.; MATTIAZZO, M. E. Lixiviação de íons inorgânicos em solos repetidamente tratados com biossólido. Revista Brasileira de Ciência do Solo, Viçosa, MG, v. 24, n. 4, p. 927-938, 2000. http://www.redalyc.org/src/inicio/ArtPdfRed. jsp?iCve $=253019677001$

BORGES JÚNIOR, J. F.; FERREIRA, P. A. Equações e programa computacional para cálculo do transporte de solutos do solo. Revista Brasileira de Engenharia Agrícola e Ambiental, Campina Grande, v. 10, n. 3, p. 604-611, 2006. http://dx.doi.org/10.1590/S1415-43662006000300010

CAMARGO, O. A. Reações e interações de micronutrientes no solo. 2006. Available in: <http://www.infobibos.com/Artigos/2006_3/micronutrientes/Index.htm>. Access in: 12 July 2012.

CHAVES, L. H. G.; SOUZA, R. S.; TITO, G. A. Adsorção de zinco em Argissolos do Estado da Paraíba: efeito do pH. Revista Ciência Agronômica, Fortaleza, v. 39, n. 4, p. 511516, 2008.

CHUI, Q. S. H. Uso da vermiculita massapé paulistana como adsorvedora de metais. Engenharia Sanitária e Ambiental, Rio de Janeiro, v. 10, n. 1, p. 58-63, 2005. http://dx.doi.org/10.1590/S1413-41522005000100007

COSTA, C. DAS N.; BISSANI, C. A.; TEDESCO, M. J. Fracionamento seqüencial de cádmio e chumbo em solos. Ciência Rural, Santa Maria, v. 37, n. 5, p. 1323-1328, 2007. http://dx.doi.org/10.1590/S0103-84782007000500016

DAL BOSCO, S. M.; JIMENEZ, R. S.; CARVALHO, W. A. Aplicação da zeólita natural escolecita na remoção de metais pesados de efluentes industriais: competição entre os cátions e processo de dessorção. Eclética Química, São Paulo, v. 29, n. 1, p. 47-56, 2004. http://dx.doi.org/10.1590/S0100-46702004000100006 
TITO, G. A.; CHAVES, L. H. G.; GUERRA, H. O. C. Effect of the bentonite application on the cadmium mobility in an Argissol. Ambi-Agua, Taubaté, v. 7, n. 2, p. 18-29, 2012. (http://dx.doi.org/10.4136/ambiagua.901)

EMPRESA BRASILEIRA DE PESQUISA AGROPECUÁRIA - EMBRAPA. Centro Nacional de Pesquisa de Solos. Manual de métodos de análise de solo. 2. ed. Rio de Janeiro: EMBRAPA Solos, 1997. 212 p.

FERREIRA, D. F. Sistema de análises estatísticas - SISVAR. Versão 4.6 (Build 60). Lavras: DEX/ UFLA, 2003.

FREEZE, R. A.; CHERRY, J. A. Groundwater. Englewood Cliffs: Prentice-Hall, 1979. $604 \mathrm{p}$.

GUIMARÃES, M. A.; SANTANA, T. A.; SILVA, E. V.; ZENZEN, I. L.; LOUREIRO, M. E. Toxidade e tolerância ao cádmio em plantas. Revista Trópica - Ciências Agrárias e Biológicas, Chapadinha, v. 1, n. 3, p. 58-68, 2008.

JESUS, S. C. Difusão de zinco em camada compactada de solo residual de gnaisse. 2004. 90f. Tese (Doutorado em Engenharia Civil) - Universidade Federal de Viçosa, Viçosa, MG, 2004.

JULIATTI, M. A.; PRADO, R. M.; BARRIQUELO, M. F.; LENZI, E. Cádmio em latossolo vermelho cultivado com milho em colunas: mobilidade e biodisponibilidade. Revista Brasileira de Ciência do Solo, Viçosa, MG, v. 26, p. 1075-1081, 2002. http://redalyc.uaemex.mx/src/inicio/ArtPdfRed.jsp?iCve=180218306026

LACIN, O.; BAYRAK, B.; KORKUT, O.; SAYAN, E. Modeling of adsorption and ultrasonic desorption of cadmium (II) and zinc (II) on local bentonite. Journal of Colloid and Interface Science, v. 292, n. 2, p. 330-335, 2005. http://dx.doi.org/10.1016/j.jcis. 2005.05.092

MALAVOLTA, E. Fertilizantes e seu impacto ambiental: micronutrientes e metais pesados, mitos, mistificação, e fatos. São Paulo: Produquímica, 1994. p. 4-121.

MATOS, A. T.; FONTES, M. P. F.; COSTA, L. M.; MARTINEZ, M. A. Mobility of heavy metals as related to soil chemical and mineralogical characteristics of Brazilian soils. Environmental Pollution, v. 111, n. 3, p. 429-435, 2001. http://dx.doi.org/10.1016/ S0269-7491 (00)00088-9

MESSIAS, A. S.; SILVA, H. A. E.; LIMA, V. N.; SOUZA, J. E. G. Avaliação da mobilidade de micronutrientes em solo tratado com lodo de esgoto. Revista Brasileira de Gestão e Desenvolvimento Regional, Taubaté, v. 3, p.193-211, 2007.

MEURER, E. J. Fundamentos de química de solo. 2. ed. Porto Alegre: Genesis, 2004. 290p.

MOREIRA, D. A.; MARTINEZ, M. A.; SOUZA, J. A. R.; MATOS, A. T.; REIS, C.; BARROS, F. M. Fatores de retardamento e coeficientes de dispersão-difusão de metais pesados em resíduos da construção civil e demolição. Revista Ambiente \& Água, Taubaté, v. 5, n. 2, p. 77-86, 2010. http://dx.doi.org/10.4136/ambi-agua.138

NASCIMENTO, R. S. MELO DO; CARVALHO, G. S.; PASSOS, L.; MARQUES, J. J. Lixiviação de chumbo e zinco em solos tratados com resíduos de siderurgia. Pesquisa Agropecuária Tropical, Goiânia, v. 40, n. 4, p. 497-509, 2010. http://www.redalyc.org/src/inicio/ArtPdfRed.jsp?iCve=253019677001

PAGANINI, W. S.; SOUZA, A.; BOCCHIGLIERI, M. M. Avaliação do comportamento de metais pesados no tratamento de esgotos por disposição no solo. Engenharia Sanitária e Ambiental, Rio de Janeiro, v. 9, n. 3, p. 225-239, 2004. http://dx.doi.org/10.1590/ S1413-41522004000300009 
TITO, G. A.; CHAVES, L. H. G.; GUERRA, H. O. C. Effect of the bentonite application on the cadmium mobility in an Argissol. Ambi-Agua, Taubaté, v. 7, n. 2, p. 18-29, 2012. (http://dx.doi.org/10.4136/ambiagua.901)

PRADO, R. M.; JULIATTI, M. A. Lixiviação de cádmio em profundidade em coluna com latossolo vermelho e nitossolo. Revista de Agricultura, Piracicaba, v. 78, n. 2, p. 219$228,2003$.

RODRIGUES, M. G. F.; SILVA, M. L. P.; SILVA, M. G. C. Caracterização da argila bentonítica para utilização na remoção de chumbo de efluentes sintéticos. Cerâmica, São Paulo, v. 50, n. 315, p. 190-196, 2004. http://dx.doi.org/10.1590/S036669132004000300004

SANTOS, C. P. F.; MELO, D. M. A.; MELO, M. A. F.; SOBRINHO, E. V. Caracterização e usos de argilas bentonitas e vermiculitas para adsorção de cobre (II) em solução. Cerâmica, São Paulo, v. 48, n. 308, p. 178-182, 2002. http://dx.doi.org/10.1590/S036669132002000400002

SILVA, F. C. DA; WEBER NETO, J.; ZANFELICI, M. R. Comparação metodológica para abertura de resíduos sólidos orgânicos urbanos na determinação dos teores totais de metais pesados. In: INTERNATIONAL CONFERENCE ON ENGINEERING AND COMPUTER EDUCATION, 2007, São Paulo. Proceedings... [S.1.]: Council of Researches in Education and Sciences, 2007, p. 501-504.

WITTBROADT, P. R.; PALMER, C. D. Reduction of Cr (IV) by soil humic acids. European Journal of Soil Science, v. 48, n. 1, p. 151-162, 1997. http://dx.doi.org/10.1111/j.13652389.1997.tb00194.x 